\title{
The spirit of capitalism and savings behavior
}

\author{
Heng-fu Zou \\ Policy Research Department, The World Bank, Room N10-075, 1818 H Street, NW, Washington DC \\ 20433, USA \\ Institute of Advanced Economic Studies, Wuhan University, Wuhan 430072, China
}

Received 6 October 1993; revised 11 January 1994

\begin{abstract}
This paper presents a capitalist-spirit model of savings by including wealth in the intertemporal utility function. While this model includes the life-cycle model and bequest model as two special cases, it sheds light on why wealth holding has tended to increase with age, why decumulation of wealth after retirement has not happened, and why households with and without children have not shown significant differences in their savings behavior. The capitalist-spirit approach is especially useful for understanding savings by the rich and savings across countries and over time (JEL E21, B10).
\end{abstract}

JEL classification: E21; B10

Keywords: Savings puzzle; Capitalist spirit, Wealth accumulation

\section{Introduction}

Many empirical studies suggest that the life-cycle theory of consumption cannot explain the "savings puzzle": why wealth does not decumulate after retirement, and why wealth holdings tend to increase with age (Atkinson (1971); Atkinson and Harrison (1978); Mirer (1979); Thurow (1976); Danziger et al. (1983). Moreover, Kotlikoff and Summers (1981) demonstrate that the pure life-cycle component of aggregate US savings has been very small and that most capital accumulation in the US occurs through intergenerational transfers. Like the life-cycle model, however, the theory of intergenerational transfer cannot fully 
explain why there exists no significant difference in the rate of asset decumulation between the elderly who have children and those who do not, which is shown by Hurd (1986); nor can it explain why there exists a positive relation between transfers and recipient's income as demonstrated in Cox (1987).

This paper proposes a possible solution to these anomalies by recalling the role of the "capitalist spirit" in the sense of Max Weber (1905), which motivates the continual accumulation of wealth not only for the material reward that it brings, but also for its own sake.

Even before Weber, Adam Smith, Nassau Senior, and Karl Marx expressed similar views, and subsequently Werner Sombart, Joseph Schumpeter, John Maynard Keynes and Gustav Cassel argued essentially the same hypothesis (Zou (1993b)). For example, Adam Smith (1776) states the following principle of savings in a capitalist society: "The principle which prompts to save... comes with us from the womb, and never leaves us till we go into the grave. ... In the greater part of men, taking the whole course of their life at an average, the principle of frugality seems not only to predominate, but to predominate very greatly" over the principle of expense or consumption (pp. 324-325).

If I express this statement by Adam Smith on the nature of the economic man in the form of a utility function, it is obvious that the utility function not only includes the expense or consumption part, but also frugality or wealth. That is, the utility function of a typical capitalist should be defined as $u(c, w)$, where $c$ is consumption and $w$ denotes wealth.

In the remainder of this paper I show how this hypothesis can be captured in the standard neoclassical savings theory as in Kurz (1968) but using an explicit generational framework. This makes it possible to incorporate the standard intertemporal savings and bequest motives as special cases. I then consider the empirical evidence already reported in the literature which can be reinterpreted from this more general point of view. Finally, I comment on the measurement of the capitalist spirit in some related studies. The present approach is strictly complementary to the existing life-cycle theory and the theory of bequest. My contribution is to explain the part of savings which cannot be explained when the capitalist spirit is not incorporated. In other words, there are three motives for savings: for retirement, for bequest, and accumulation for its own sake.

\section{The capitalist spirit in an overlapping-generations model of savings}

Consider a typical agent of the $i$-th generation who lives for two periods. He consumes $c_{i, 1}$ in period 1 and $c_{i, 2}$ in period 2, saves $w_{i, 1}$ in period 1 and $w_{i, 2}$ in period 2 , and derives a discounted utility over the two periods:

$$
u\left(c_{i, 1}\right)+\beta v\left(w_{i, 1}\right)+\frac{u\left(c_{i, 2}\right)+\beta v\left(w_{i, 2}\right)}{1+\delta},
$$


where $(1+\delta)^{-1}$ is the positive time discount factor; $\beta v($.$) is the utility derived$ from wealth accumulation itself and the parameter $\beta$ is used to measure the capitalist spirit, and can take any value from zero to positive infinity. [I exclude negative values of $\beta$ or Wittgenstein's view that money is a nuisance (Russell (1968), p. 144).] When $\beta$ equals zero, this is the standard utility function as in Diamond (1965); when the term $\beta v\left(w_{i, 1}\right)$ is dropped for the first period but retained for the second, this is the standard bequest models like Blinder's [Blinder (1973)]. It is further assumed that both functions $u($.$) and v($.$) are increasing,$ concave and differentiable in their arguments: $u^{\prime}()>0,. v^{\prime}()>0,. u^{\prime \prime}()<$.0 , and $v^{\prime \prime}()<$.0 .

For simplicity, population growth is assumed to be zero. I normalize the number of individuals in each cohort to be one. Thus generation $i$ or agent $i$ receives an amount of wealth $w_{i-1,2}$ from the generation $(i-1)$. This wealth is left behind by agent $(i-1)$, while the old generation has already derived the discounted utility $(1+\delta)^{-1} \beta v\left(w_{i-1,2)}\right.$ from the holding of wealth $w_{i-1,2}$. In addition to the wealth left over by the old generation, individual $i$ receives an income $y$ when he is young. Again for simplicity, this income is assumed to be the same for all generations and the interest rate on savings is also fixed at a constant $r$ for all generations. Therefore, we can write the budget constraint for the typical generation $i$ as follows:

$$
\begin{aligned}
& w_{i, 1}=y+(1+r) w_{i-1,2}-c_{i, 1}, \\
& w_{i, 2}=(1+r) w_{i, 1}-c_{i, 2} .
\end{aligned}
$$

Here Eq. (2) says that generation $i$ 's total income $\left[y+(1+r) w_{i-1,2}\right]$ is allocated between first-period consumption $c_{i, 1}$ and first-period savings $w_{i, 1}$. Eq. (3) says that the total first-period savings plus the interest income is used for the second-period consumption $c_{i, 2}$ and the second-period savings $w_{i, 2}$.Maximizing (1) subject to (2) and (3) yields the first-order conditions:

$$
\begin{aligned}
& \beta v^{\prime}\left(w_{i, 2}\right)=u^{\prime}\left(c_{i, 2}\right), \\
& \beta v^{\prime}\left(w_{i, 1}\right)+\frac{(1+r)}{(1+\delta)} u^{\prime}\left(c_{i, 2}\right)=u^{\prime}\left(c_{i, 1}\right) .
\end{aligned}
$$

Combining (2)-(5), savings in periods 1 and 2 can be expressed as:

$$
\begin{aligned}
& \beta v^{\prime}\left(w_{i, 2}\right)=u^{\prime}\left((1+r) w_{i, 1}-w_{i, 2}\right), \\
& \beta v^{\prime}\left(w_{i, 1}\right)+\frac{(1+r)}{(1+\delta)} \beta v^{\prime}\left(w_{i, 2}\right)=u^{\prime}\left(y+(1+r) w_{i-1,2}-w_{i, 1}\right) .
\end{aligned}
$$

Differentiating $w_{i j}, j=1,2$, with respect to $\beta$, I obtain:

Proposition 1. The higher the capitalist spirit, the higher the savings in both periods 1 and 2. 
Rearranging optimal conditions (4) and (5), I have:

$$
\frac{v^{\prime}\left(w_{i, 1}\right)}{v^{\prime}\left(w_{i, 2}\right)}=\frac{u^{\prime}\left(c_{i, 1}\right)}{u^{\prime}\left(c_{i, 2}\right)}-\frac{(1+r)}{(1+\delta)} \text {. }
$$

From which, the movement of the wealth ratio $\left(w_{i, 1} / w_{i, 2}\right)$ can be seen:

Proposition 2. Savings increase (decrease) with age, that is, $w_{i, 1} / w_{i, 2}<1$ $\left(w_{i, 1} / w_{i, 2}>1\right)$, if the marginal rate of substitution between consumption in period 1 and consumption in period 2 is larger (smaller) than $(2+r+\delta)(1+\delta)^{-1}$.

The proof comes directly from expression (8). Suppose that $w_{i, 1} / w_{i, 2}$ is less than one, that is to say, savings in the second period are higher than in the first period. Then the left-hand side of Eq. (8) is larger than one since the function $v($.) is concave. To maintain equality, the right-hand side has to be bigger than one, which means that the marginal rate of substitution between consumption in period 1 and consumption in period 2 minus $(1+r)(1+\delta)^{-1}$ is larger than one, or the marginal rate of substitution is larger than $(2+r+\delta)(1+\delta)^{-1}$. The proof of the other case is similar.

From proposition 2, we can see the movement of consumption in the two periods corresponding to changes in savings. If the wealth ratio $w_{i, 1} / w_{i, 2}$ is less than, or equal to, one, the marginal rate of substitution $u^{\prime}\left(c_{i, 1}\right) / u^{\prime}\left(c_{i, 2}\right)$ is greater than, or equal to, $(2+r+\delta)(1+\delta)^{-1}$, which is greater than one. Then, by concavity of $u($.$) , the ratio of the consumption in period 1$ over that in period 2 , $c_{i, 1} / c_{i, 2}$, is less than one, or $c_{i, 1}<c_{i, 2}$. This observation leads to:

Proposition 3. If second-period savings are larger than, or equal to, first-period savings: $w_{i, 2} \geq w_{i, 1}$, then second-period consumption is no less than first-period consumption: $c_{i, 2} \geq c_{i, 1}$.

In order to see the effect of the capitalist spirit on the wealth ratio clearly, let $u(c)=\log c$ and $v(w)=\log w$. Then, the first-order conditions become:

$$
\begin{aligned}
& \frac{\beta}{w_{i, 2}}=\frac{1}{c_{i, 2}}, \\
& \frac{\beta}{w_{i, 1}}+\frac{(1+r)}{(1+\delta) c_{i, 2}}=\frac{1}{c_{i, 1}} .
\end{aligned}
$$

Substituting (9) into the budget constraint (3):

$$
\frac{w_{i, 2}}{w_{i, 1}}=\frac{(1+r) \beta}{1+\beta} .
$$


This gives:

Proposition 4. Second-period savings are higher (less) than first-period savings if $r \beta>(<) 1$ or if the capitalist spirit $\beta$ is larger (smaller) than $(1 / r)$.

In this special case, Proposition 2 can be strengthened:

Proposition 5. The ratio of savings over the two periods, $\left(w_{i, 2} / w_{i, 1}\right)$, increases in the capitalist spirit $\beta$.

That is,

$$
\frac{d\left[\frac{w_{i, 2}}{w_{i, 1}}\right]}{d \beta}=\frac{1+r}{1+\beta^{2}}>0 .
$$

I continue to use the special case to illustrate the path of wealth accumulation or savings over time and from one generation to another generation. Using the budget constraints (2) and (3) and the first-order conditions (9) and (10), I obtain the following relation between second-period savings of the $i$-th generation and second-period savings of the $(i-1)$-th generation:

$$
w_{i, 2}=\frac{(1+r)(2+\delta) \beta^{2}+\beta(1+r)}{(1+\beta)^{2}(2+\delta)}\left[y+(1+r) w_{i-1,2}\right]
$$

From this, it follows that:

Proposition 6. When the capitalist spirit is strong, each generation will bestow more and more wealth to the next generation.

That is,

$$
\frac{d w_{i, 2}}{d w_{i-1,2}} \rightarrow(1+r)^{2}>1 \text { for the large values of } \beta .
$$

\section{Empirical evidence}

\subsection{Savings behavior of the old in empirical studies}

According to the standard life-cycle theory of savings, old people are supposed to decumulate their wealth after retirement. But from the perspective of the capitalist-spirit model, savings in old age can be higher than in young age as 
suggested by propositions 4 and 5 . This theoretical result has strong support in empirical studies on the savings behavior of the old since the 1970s.

Atkinson (1971) and Atkinson and Harrison (1978) show that average wealth accumulation in Britain increases in old age. Brittain (1978) finds a positive relationship between age and wealth holdings in the United States. Mirer (1979) examines wealth holding patterns among aged married couples from the 1968 survey of the Demographic and Economic Characteristics of the Aged and finds that wealth (not including the capital value of pensions, social security, etc) declines modestly, or perhaps not at all, with age. This observation not only applies to the very rich, but also holds for all other levels of wealth. Furthermore, after correcting for intercohort differences in wealth at retirement, he shows that wealth increases with age. Menchik and David (1983) also fail to show individuals decumulating wealth in old age, and, on the contrary, the opposite result seems to hold in their study. As for the saving rate, Thurow (1976) finds positive saving rates for all age groups. Danziger et al. (1983) show that the elderly not only do not dissave to finance their consumption during retirement, they spend less on consumption goods and services (save significantly more) than the non-elderly at all levels of income. Moreover, the oldest of the elderly save the most at given levels of income.

Intergenerational transfers have been used to explain this increasing relationship between wealth and age. But empirical studies have cast some doubt on this motive. According to the bequest theory, children with low income should receive more transfer income from their parents than the children with high income from the same family. But statistical studies have shown the opposite. For example, Sussman et al. (1970), Brittain (1978) and Menchik (1980) all have found that wealth bequeathed to children is shared equally, while Cox (1987) finds a positive relation between the transfers and the recipient's income.

All these facts are consistent with the capitalist-spirit model of savings. Since savings themselves also generate utility, the old keep saving even though the life-cycle motive tends to reduce savings. Furthermore, as strong capitalist-spiritminded parents may encourage their children to have the same spirit, they will give equal or more money to those children with a strong capitalist spirit and high income than to their children with low income. This positive association between recipients' income and bequest also points out that the parents have tried to encourage industriousness and savings of their children.

\subsection{Savings behavior of households with and without children}

Perhaps the most important challenge to the bequest theory of savings, and a more significant piece of supporting evidence for the capitalist-spirit theory of savings, comes from Hurd (1986). One may expect that the bequest motive depends on whether the old have children. But, with the data from the Longitudinal Retirement History Survey (RHS), Hurd finds that households with children 
and without children do not show any significant difference in their dissavings. In fact the opposite is true: "the households with children have less bequeathable wealth than households without children. If the observed rates of decumulation continue beyond the ages of the RHS households, the households with children will always have less wealth than households without children"' (p. 32-33). Hurd also finds that the saving rates of households without children are always higher than the saving rates of households with children. While Hurd's finding challenges the bequest motive of savings, it implies that savings can be undertaken for the sake of savings regardless of whether a household has children or not. Hurd hints that the existing methods cannot be used to study the savings behavior of the very wealthy: "If one wants to understand how the capital stock is accumulated, one would probably want to study the very wealthy. However, the standard consumption models may not apply: time constraints prevent the very wealthy from consuming even the interest from their wealth"' (p. 35). The capitalist-spirit theory of savings seems to offer an alternative to the existing models of savings.

\subsection{Savings psychology of the rich}

The rich have most of the wealth in most countries. For example, in Britain, the top 1 percent of the adult population own about a third of the total personal wealth and the top 10 percent as much as three-quarters (Atkinson (1971), p. 239). Empirical studies have demonstrated some different patterns of savings for the rich. Burbridge and Robb (1985) show that, among Canadian households, there exists a significant difference in accumulation behavior among the rich and the poor; on average, "blue-collar" households decumulate after retirement and "white-collar" do not.

While it is difficult to offer a regression analysis about the savings behavior of the very rich and the "captains of industry", their savings habit and their "spirit of accumulation" can be seen from their confessions and many case studies. The first example is taken from Weber (1958):

"When Jacob Fugger, in speaking to a business associate who had retired and who wanted to persuade him to do the same, since he had made enough money and should let others have a chance, (they are the followers of the life-cycle theory, added), rejected that as pusillanimity and answered that "he (Fugger) thought otherwise, he wanted to make money as long as he could."' (p. 51).

Many examples are presented in Sombart's (1915) book. For example, Sombart cites Andrew Carnegie's Autobiography: "We were always hoping ... that there would come a time when extension of business would no longer be necessary; but we invariably found that to put off expanding would mean retrogression"'. (p. 174) He also quotes Rockefeller: "The more the business grew the more capital we put into it, the object being always the same: to extend our business". (p. 174)

Having studied the money-making careers of many "captains of industry", Sombart offers the following observation on their savings psychology: "It fre- 
quently happens that he really does not want to expand further, but he must. Many a captain of industry has confessed as much... Most capitalist undertakers think nothing else but this desire for extension and expansion, which to the outside observer appears so meaningless" (pp. 174-175). This expansion psychology leads to ever-increasing savings. If you interpret their behavior as saving and investing for the future or for the next generation, captains of industry will quickly dismiss this intention and "regard you with a kind of mild surprise" (p. 175).

Wicksteed (1933) has the following description of the savings psychology of the rich: "A millionaire is not only able to save but unable not to save, because he cannot spend all his accumulation at once, and he is always able to transmute present into future command of wealth". (p. 294). "Indeed to the rich man the problem often is how he can avoid saving too much. The exigencies of his business may drain him of his income. It is always demanding to be extended, till he no longer controls it, but it controls him. It has become a kind of Frankenstein's monster that dominates his life. It must grow or die. And he cannot let it die, partly because he is dependent upon it, and partly because it has become a kind of entity to him, and, independently of all the things in the circle of exchange that it represents to him, has acquired a kind of independent claim upon his affection and his imagination, and is bound up with all manner of personal relations and obligations". (p. 298).

\subsection{The connection between the capitalist spirit and savings over time}

The role of the capitalist spirit in the economic take-off from a traditional society to a modern capitalist economy has manifested in two aspects: first, the capitalist spirit contributes to a higher saving rate; and second, the capitalist spirit cannot be separated from entrepreneurship in the sense of Joseph Schumpeter as I have argued in Zou (1993b). As observed by Rostow (1960), the economic take-off from a traditional society to an industrialized society requires a significant increase in the saving or investment rate from about 5 percent of national income to about 10 percent. How does one explain this phenomenon? According to Weber and Sombart, the attitudes towards acquisition, savings and wealth accumulation are very different between a traditional society on one hand and a capitalist society on the other. While in the traditional society the normal situation for mankind is that rationally acquisitive activities are oriented to a traditionally fixed standard of living and the saving rate is rather low, in the capitalist era, the traditional practice is broken down and acquisition has become an endless process. From the historical perspective, the Protestant ethic is the psychological origin of this capitalist spirit because the Protestant ethic - hard work, thrift, austerity - "must have been the most powerful conceivable lever for the expansion of that attitude toward life which we have called the spirit of capitalism". These ethos also have a direct implication for the rising saving rates: "when the limitation of consumption is combined with this release of acquisitive activity, the inevitable practical result is 
obvious: accumulation of capital through ascetic compulsion to save". (Weber (1905), p. 172, italics added.)

Mill (1848) also takes the capitalist-spirit approach to study economic growth in the 17th to the 19th-century Europe. In England as well as other prosperous countries of Europe, "in a very numerous portion of the community, the professional, manufacturing, and trading classes, being those who, generally speaking, unite more of the means with more of the motives for saving than any other class, the spirit of accumulation is so strong, that the signs of rapidly increasing wealth meet every eye". (p. 173, italics added). What are the causes of this accumulation phenomenon? After citing numerous economic, political, institution factors, Mill adds the following: "These causes have, in England, been greatly aided by what extreme incapacity of the people for personal enjoyment, which is a characteristic of countries over which puritanism has passed". (p. 174) According to Mill, the spirit of accumulation is even higher in Holland where "the mercantile classes...remained frugal and unostentatious" (p. 175).

Mill paid particular attention to the puzzle between low returns and rapid accumulation in his time. His explanation emphasizes the spirit of accumulation. As long as the spirit of accumulation is strong, high returns are not needed to stimulate savings: "In England and Holland, then, for a long time past, and now in most other countries in Europe... the desire of accumulation does not require, to make it effective, the copious returns which it requires in Asia, but is sufficiently called into action by a rate of profit so low, that instead of slackening, accumulation seems now to proceed more rapidly than ever'. (p. 175, italics added.)

Keynes (1920) also emphasizes the role of "the saving for the sake of savings", in the vast accumulation of capital in the 19th-century Europe: "Europe was so organized socially and economically as to secure the maximum accumulation of capital. While there was some continuous improvement in the daily conditions of life of the mass of the population, society was so framed as to throw a great part of increased income into the control of the class least likely to consume it. The new rich of the nineteenth century were not brought up to larger expenditures, and preferred the power which investment gave them to the pleasure of immediate consumption". (pp. 18-19, italics added.)

While a strong capitalist spirit has led to rapid capital accumulation and fast economic growth, the waning of the capitalist spirit has been the main cause of the "British disease"' as diagnosed by Sombart (1915), Henry Rosovsky [in Harrison (1992)], and Wiener (1982). Once the "captains of industry" have lost their wholehearted pursuit of money and profits, and once people have developed their contempt for the capitalist spirit, then a declining trend of savings and economic growth is inevitable. While blaming large government deficits and borrowing as the main cause of very low saving rates in the US, Harrison (1992) is very careful to point out the fundamental change in the American cultural values. According to Harrison, the traditional American values such as hard work, frugality and austerity, namely, the strong capitalist spirit of America, have been eroded 
gradually, "disrespect for thrift and austerity, driven by increased focus on the present and reduced focus on the future, has a lot to do with our low national levels of savings and investment"'. (p. 230)

\subsection{The Confucianist ethic of frugality and high saving rates of East Asia}

Many studies on high saving rates in East Asian countries and regions like Japan, Taiwan, South Korea, Singapore and Hong Kong have taken the capitalistspirit approach modified to the Confucianist ethic of frugality. In explaining the economic success of Japan, Morishima (1982) places the Confucianist ethic of frugality on equal footing with the Protestant ethic: while the Protestant ethic is the origin of the capitalist spirit in the West, the Confucianist ethic of frugality is the origin of the capitalist spirit in Japan. Since Morishima does not explain the Confucianist moral of frugality, I present some idea of the Confucianist teaching on frugality here; more details appear in Zou (1993a).

The Confucianist ethic of frugality is expressed in the doctrine of Confucius (born 552 B.C.), the founder of the Confucianist school. Since the early Han Dynasty (B.C. 206-220 A.D.) until the early 20th century, Confucianism was the official ideology of China. The adoption of Confucianism in Korea and Japan resulted in the Korean Confucianism and the Japanese Confucianism. Even today, the moral teachings in these countries and other countries like Taiwan, Singapore and Hong Kong all have their origin directly from Confucianism. In the most famous Chinese classic The Analects (Confucius (1986), English edition), Confucius states the following moral codes on frugality:

"The Master (Confucius) said, 'In guiding a state of a thousand chariots, approach your duties with reverence and be trustworthy in what you say; be frugal in spending and love your fellow men"' (Book I, 5).

"Lin Fang asked about the basis of the rites. The Master said, "A noble question indeed! With the rites, it is better to err on the side of frugality than on the side of extravagance"" (Book III. 4).

"The Master said, 'Extravagance means ostentation, frugality means shabbiness. I would rather shabby than ostentatious", (Book VII. 36).

The Confucianist ethic of frugality plays a very important role in promoting high savings in China. It is absolutely right to attribute fast economic growth in the past 15 years to economic reforms initiated by Deng Xiaoping. But why have the Chinese people with a low per capita income kept an average saving rate of 34\%? Perhaps this is the reason why most experts on China and East Asia have advocated so much the role of the Confucianist values in generating high saving rates and fast economic growth in those countries; see Harrison (1992) and many references in Harrison's book.

When Hayashi (1986) makes a detailed examination “'Why is Japan's saving rate so apparently high?", he lists cultural factors as one of the explanatory factors (p. 167). The paper by Hirioka (1985) has also shown some mixed evidence on the 
relation between the culture and high saving rates in Japan. There is also an interesting observation made by Lawrence Summers and one of his students appeared in Hayashi (1986): "Summers suggested cultural difference between Japanese and Americans as a possible explanation of the high saving rate in Japan. He cited a work based on survey data for Japanese-Americans by one of his students. The research showed that Japanese-Americans' saving rate is 5 percent higher than that of the other group". (p. 234)

\section{Conclusion}

Our theoretical model which includes the life-cycle motive and bequest motive captures the essence of wealth accumulation in a capitalist economy: accumulation for the sake of accumulation. It indicates that, with a strong capitalist spirit, people may not decumulate their wealth in retirement, but continue to accumulate generation after generation. The empirical evidence strongly supports the role of the accumulation motive. First, the old do not generally decumulate wealth during retirement. On the contrary, they tend to keep saving until they die. Second, households with and without children do not have significant differences in their savings behavior. Moreover, the capitalist-spirit model of savings realistically characterizes the savings behavior of the very wealthy, and explains why there is a significant upward jump in the saving rates when a traditional society becomes a modern capitalist economy. It implies that saving rates will be different across countries if the intensity of the capitalist spirit is different. In particular, the model sheds light on high saving rates in East Asian countries endowed with the Confucianist ethic of frugality.

Naturally, the measurement of the capitalist spirit is a problem. This is exactly the issue discussed by Lucas (1988) in this theory of human capital and endogenous growth. Lucas admits that, even though human capital accumulation is the engine of growth in his model, "we can no more directly measure the amount of human capital a society has, or the rate it is growing, than we can measure the degree to which a society is umbued with the Protestant ethic"' (p. 35). Lucas regards the concept of human capital equivalent to "the Protestant ethic, or the spirit of history or just "factor X"', or the capitalist spirit because these concepts all have the same measurement problem. An approximation to measuring the capitalist spirit has been done by DeLong (1988). He takes the dominant religious establishment in a nation as a dummy variable with value one for a country with dominant Protestants, value zero for a country with dominant Catholics, and one-half for a country with half Catholics and half Protestants. He finds that the GDP per capita from 1870 to 1979 for once rich twenty-two countries in 1870 was significantly positively correlated with this religious dummy variable. In fact, the measurement of the capitalist spirit is no more difficult than the measurement of the desire for intergenerational transfers in the standard savings models; it is no 
more difficult than the measurement of time preference and the elasticity of the intertemporal substitution in almost all dynamic models. As usual, the capitalistspirit model can be calibrated to stimulate the savings patterns in a country and across countries; or one can follow the Lucas-DeLong approximation to the capitalist spirit by choosing a dummy variable of dominant religious establishments across countries; or, for East Asia countries, one can follow Morishima's suggestion to take the degree of exposure to the Confucianist ethic of frugality as another possible candidate. In the end, it should be noted that this so-called latent variable problem discussed here is very common in economics and other social sciences. [For the interested reader, see Aigner and Goldberger (1977).]

\section{For further reading}

Zou (1994), Zou (1995), and Bakshi and Chen (1995).

\section{Acknowledgements}

I thank John Campbell, Richard Caves, Shantayanan Devarajan, Dwight Perkins and Jeffrey Sachs for discussions, criticism and suggestions. I am especially indebted to Richard Day for detailed suggestions, editorial help and encouragement, which led to a total revision of this paper. All remaining errors are my own. The views expressed here do not necessarily reflect those of the World Bank.

\section{References}

Aigner D. and A. Goldberger, 1977, (eds.) Latent variable in socio-economic models. North-Holland, Amsterdam.

Atkinson, Anthony. 1971, The distribution of wealth and the individual life-cycle, Oxford Economic Papers 23, 239-254.

Atkinson, Anthony and A.J. Harrison, 1978, The distribution of wealth in Britain (Cambridge University Press).

Bakshi, Gurdip, and Zhiwu Chen, 1995, The spirit of capitalism and stock market prices, forthcoming, American Economic Review.

Blinder, Alan, 1973, A model of inherited wealth, Quarterly Journal of Economics 87, 608-626.

Brittain, John, 1978, Inheritance and the inequality of material wealth (The Brookings Institution, Washington, D.C.).

Burbridge, J.B. and A.L. Robb, 1985, Evidence on wealth-age profiles in Canadian cross section data, Canadian Journal of Economics 18, 854-875.

Confucius, 1986, The analects, translated by D.C. Lau (Dorset Press, New York).

Cox, Donald, 1987, Motives for private income transfers, Journal of Political Economy 95, 508-546.

Danziger, Sheldon, Jacques van der Graag, Eugene Smolensky and Michael Taussig, 1983, The life-cycle hypothesis and the consumption behavior of the elderly, Journal of Post Keynesian Economics 5 (2), 208-227. 
DeLong, B., 1988, Productivity growth, convergence and welfare: comment, American Economic Review.

Diamond, Peter, 1965, National debt in a neoclassical growth model, American Economic Review 55, 1126-1150.

Hayashi, Fumio, 1986, Why is Japan's saving rate so apparently high?, Stanley Fischer, (ed.) NBER Macroeconomics Annual 1986 (The MIT Press), 147-234.

Harrison, Lawrence, 1992, Who prospers? How cultural values shape economic and political success (Basic Books).

Hirioka, C., 1985, A survey on the literature on household saving in Japan: why is the household saving rate so high in Japan?, Mimeo (Kyoto University).

Hurd, M.D., 1986, Savings and bequests, NBER working paper 1826 (Cambridge, MA).

Keynes, J.M., 1920, The economic consequences of the peace (Harcourt, Brace and Howe).

Kotlikoff, Laurence and Lawrence Summers, 1981, The role of intergenerational transfers in aggregate capital formation, Journal of Political Economy 89, 706-732.

Kurz, M., 1968, Optimal economic growth and wealth effects, International Economic Review 9, 348-57.

Lucas, R.E., 1988, On the mechanics of economic development, Journal of Monetary Economics 22, 3-42.

Menchik, P.L., 1980, Primogeniture, equal sharing and the US distribution of wealth, Quarterly Journal of Economics 94 (2), 229-316.

Menchik, Paul and Martin David, 1983, Income distribution, lifetime savings and bequests, American Economic Review 73, 672-690.

Mill, J.S., 1848, (1st edition), Principles of political economy, Edited by W.A. Ashley, Longman, Green and Co (1909).

Mirer, Thad W., 1979, The wealth-age relation among the aged, American Economic Review 69, 435-443.

Morishima, M., 1982, Why has Japan “'succeeded"'? (Cambridge University Press).

Rostow, W., 1960, Stages of economic growth (Cambridge University Press).

Russell, Bertrand, 1968, The autobiography of Bertrand Russel: 1914-1944 (Little, Brown and Company, Boston).

Smith, Adam, 1776, The wealth of nations, (Modern Library, New York, 1930).

Sombart, W., 1915, The quintessence of capitalism (New York: Dutton), translated and edited by M. Epstein.

Sussman, M.B., J.N. Cates and O.T. Smith, 1970, Inheritance and the family (Sage, New York).

Thurow, L., 1976, Generating inequality (Basic Books, New York).

Weber, M., 1905, The protestant ethic and the spirit of capitalism (Charles Scribner's Sons, New York, 1958).

Wicksteed, Philip H., 1933, The common sense of political economy, 2 volumes (Routledge \& Kegan Paul).

Wiener, M., 1982, English culture and the decline of the industrial spirit, 1850-1980 (Cambridge University Press).

Zou, Heng-fu, 1993a, Economic growth, the capitalist spirit and thrift, Journal of Economic Research, February, 56-64 (Chinese Academy of Social Sciences, Beijing).

Zou, Heng-fu, 1993b, The capitalist-spirit approach to growth: A perspective from the history of economic analysis. Revised for History of Political Economy.

Zou, Heng-fu, 1994, The spirit of capitalism and long-run growth, European Journal of Political Economy 10, No. 2, 279-293.

Zou, Heng-fu, 1995, The spirit of capitalism, savings, asset prices and growth, forthcoming, The World Bank and Wuhan University. 